\title{
Public Service Policy in the COVID-19 Emergency Period
}

\author{
Syarif $^{1}$, Faisal Santiago ${ }^{2}$ \\ \{syarifunborr@gmail.com ${ }^{1}$, faisalsantiago@borobudur.ac.id²\} \\ Universitas Borobudur, Jakarta, Indonesia ${ }^{1,2}$
}

\begin{abstract}
This article presents public service policies during the Covid 19 emergency. By using a qualitative approach and normative juridical research methods, as well as data collection of literary studies to be descriptively analyzed to obtain comprehensive conclusions. The analysis results found that during the Covid-19 emergency, public service policies are integrated from the central to the regions. The local government must support the Central government's regulations and policies in policy, innovation, and implementation. Good policy and political support will result in good public services as well.
\end{abstract}

Keywords: Covid 19; Policy; Public

\section{Introduction}

Public help includes the broadest part of life. In the existence of the express, the public authority has a capacity to offer public types of assistance required by the local area, both as guidelines and in administrations. It turns into the premise that public administrations are given to the local area through government authorities who are obliged to fill in as state workers, yet truth be told, as of recently the vast majority actually have bad quality public administrations, particularly felt by individuals in the areas. Working on the nature of public administrations is something essential, taking into account that a bigger society will change the nature of public administrations while the act of its execution doesn't encounter huge changes.

Law Number 25 of 2009 concerning Public Services in Article 1 section (1) expresses that public administrations are exercises or series of exercises with regards to satisfying assistance needs following legal guidelines for each resident and occupant of products, administrations, nor authoritative administrations given by open specialist organizations. [1] In the public administrations execution, a mind-boggling direction to power has made the organization progressively far off from its main goal which is to offer public types of assistance. The organization and its authorities place themselves more as rulers than as community workers. Accordingly, the demeanor and conduct of the organization openly benefits execution will generally overlook the yearnings and interests of the local area. Admittance to administrations and the nature of public administrations regularly contrast contingent upon their nearness to the regulatory and political first class. Things like this frequently upset the feeling of equity in 
a general public that feels they are being dealt with unjustifiably by the public administration.[2]

In the current basic state of society, the public organization can offer public types of assistance that are more expert, successful, basic, straightforward, open, opportune, responsive, and versatile. Furthermore, simultaneously, can assemble human quality in the feeling of expanding the limit of people and society to adequately effectively decide their future. Strategies for the usage of state mechanical assembly to work on the nature of administrations should be completed reliably by considering the local area's requirements and assumptions with the goal that taxpayer supported organizations to the local area ought to consistently be given rapidly, precisely, efficiently, straightforwardly, basically, and easily, and not prejudicial. Along these lines, endeavors to work on the nature of administration to the local area are exercises completed constantly and consistently by all levels of the state mechanical assembly at all help levels to accomplish the normal uprightness.

The public authority, as a public specialist co-op, is mindful and keeps on endeavoring to offer the best support to the local area. The inferior quality of public administrations given by government authorities is a terrible picture of the public authority locally. Certain individuals who have managed the organization consistently gripe and are frustrated with the administrations gave. There are certain individuals as of recently is still disparage the presentation of the organization. Therefore, many help clients or the public pursue faster routes utilizing the administrations of representatives to deal with their necessities identified with the public authority organization.

The administrations gave overall have not fulfilled the local area. The administrations gave are excessively tangled to different reasons that are not satisfactory to the local area that the administrations offered will generally be inadequate and effective. The present circumstance makes the general population as clients of public administrations disappointed. Every one of them brought about individuals being hesitant to deal with everything straightforwardly identified with the public authority administration. The nature of public administrations is the degree to which a public office offers types of assistance to general society. The public authority is needed to offer quality public types of assistance. The connection among quality and administration is expressed by Sampara Lukman that: administration quality is administration given to clients adhering to support guidelines that have been normalized as rules in offering types of assistance. The help standard is an action that not set in stone as a norm of good assistance.[3]

Concerning the presence of a crisis brought about by the Covid 19 Pandemic, the strategy gave by the public authority is Social Distancing which is feasible to lessen or restrain the spread of the infection. This strategy is exceptionally powerful by keeping debilitated individuals from connecting with others who are not sick to forestall transmission. In like manner, wellbeing laborers attempt to upset the expansion of contaminated individuals, and it is important to ensure work assurance and security for clinical staff in taking care of Corona Virus Disease 2019 (COVID-19). Strategies identified with wellbeing administrations can be a critical part of conditions in the present society.

The crisis because of Covid-19 inside the system of a unitary state isn't just the obligation of the focal government yet in addition the neighborhood legislatures' jobs and obligations. Nearby states need to enhance strategies for taking care of the Covid-19 pandemic without abrogating the gave approaches by the focal government.[4] Moreover, in nearly 12 months, the focal government and neighborhood legislatures have started the execution of the transformation of another propensity request or "new ordinary" locally. It is on the grounds that Indonesia can't wait in the Covid-19 circumstance, with the financial and social parts of 
society declining because of the continuous Covid-19 pandemic. Besides, there should be an essential arrangement worked by the focal and local legislatures in light of the new ordinary request in the public arena while as yet focusing on wellbeing conventions and forestalling the spread of Covid-19. Therefore, it is intriguing to analyze the earnestness of public help approaches from the public authority in dealing with the Covid-19 pandemic.

\section{Method of the Study}

This research uses normative methods or library research, which research examines document studies, which uses secondary data such as legislation and the opinions of academics. Literature Studies are used to investigate the laws and regulations of books, scientific magazines, journals, results of previous research, articles, indexes, and encyclopedias related to the studied materials.

\section{Discussion}

The course of legislative issues and government democratization today doesn't just request demonstrable skill and the capacity of the contraption in broad daylight benefits yet in addition on a very basic level requests the acknowledgment of good administration that is perfect and liberated from debasement, conspiracy, and nepotism (great administration and clean government).[5] Good administration is an administration the board idea that means to make an expert government execution that is liberated from defilement, intrigue, and nepotism $(\mathrm{KKN})$.

Great administration being referred to is the most common way of executing state power in doing the arrangement of public labor and products called administration (government or administration), in the interim, the best practice is designated "acceptable administration." For "great administration" to turn into a reality and run well, it requires the responsibility and association, everything being equal, to be specific the public authority and the local area. Viable great administration requires great arrangement and honesty, demonstrable skill, hard working attitude, and high resolve. In this manner, the idea of "good administration" application in the organization of state government power is a test in itself.[5]

In the strategy report, the United Nation of Development Program (UNDP) named "Administration for reasonable human turn of events," characterizes administration as "Administration is the activity of the monetary, political, and managerial creator to deal with a country's issues at all levels and means by which state being of their populace."[6] "Government is the activity of power/power in the financial, political and authoritative fields to oversee different state issues at each level and is an instrument of state strategy to support the formation of states of government assistance, trustworthiness, and social cohesiveness in the public arena."

Notwithstanding the standards set forward by UNDP, the laws and guidelines of the Republic of Indonesia additionally direct the standards or standards of good administration, to be specific Article 3 of Law Number 28 of 1999 concerning State Organizers that are Clean and Free from Corruption, Collusion and Nepotism expressed the overall standards of state organization

a. The rule of legitimate assurance, specifically the propose in a condition of law that focuses based on enactment, respectability, and equity in each arrangement of state executives; 
b. The Principle of Orderly State Administration, in particular the rule that frames the reason for the request, agreement, and equilibrium in controlling the organization of the State;

c. The standard of the public interest, to be specific the propose that focuses on the overall government assistance in an optimistic, accommodative, and particular way;

d. The standard of transparency, to be specific the rule that opens oneself to one side of the local area to acquire right, legit, and non-biased data about state organization while as yet focusing on the security of the individual, gathering, and State mysteries;

e. The guideline of proportionality, to be specific the hypothesize that focuses on the harmony between the privileges and commitments of state directors;

f. The guideline of polished methodology, specifically the hypothesize that focuses on aptitude dependent on a code of morals and the arrangements of the appropriate laws and guidelines;

g. The guideline of responsibility is the rule that establishes that each activity and the endproduct of the exercises of the state organization should be responsible to the local area or individuals as the holder of the greatest power of the state following the arrangements of the appropriate laws and guidelines.

Aside from the overall standards of administration contained in Law Number 28 of 1999 concerning State Organizers that are Clean and Free from Corruption, Collusion, and Nepotism, the public authority should likewise have vote based standards so all that the public authority jars be observed and condemned by the local area for the formation of general success.

The idea of good administration in Indonesia that should be applied by the public authority, both focal and neighborhood legislatures, is set apart by the issuance of Law Number 28 of 1999 concerning State Organizers that are Clean and Free from Corruption, Collusion, and Nepotism. The State Administration Agency and the Financial and Development Supervisory Agency have made another module to mingle the Performance Accountability System for Government Agencies (AKIP) starts with a conversation of the idea of Good Governance and has for some time been associated in different government workplaces, and some are coordinated by non-legislative foundations like Non-Governmental Organizations Society and Universities.

Terrible showing of public administrations is the aftereffect of the intricacy of the issues that exist in the organization, including the shortfall of an impetus framework, deficient degrees of carefulness, or taking drives that are portrayed by a significant degree of reliance on proper standards and authority guidelines in completing help undertakings. Public administrations completed by the public authority are driven by guidelines and recompenses and not driven by missions. The presence of a high culture of paternalism implies that the contraption puts the authority as the primary need, not focusing on the local area's inclinations.

Judging from the hierarchical status, the regional government is the representative of the central government in the region in the implementation of specific affairs. However, then again, the territorial government conveys the status as the agent of individuals in the locale, that with its independent power, can direct and deal with its family for the interests and government assistance of individuals in the area.[7] Therefore, it is said that decentralization carried out in the regions has political and economic purposes. Political goals can be seen to strengthen the position of local governments, local government officials, and local communities and maintain national integration within the framework of a unitary state. Meanwhile, the economic goals can be seen from the efforts made by local governments to provide public services to the community.[8] 
This inadequate capacity of organizing direction and oversight causes the locales to appear to turn out well for them to tackle issues that emerge during the zones. It makes the feeling that the focal and provincial legislatures have not yet had a solitary point of view in carrying out independence. Checking out the things that have been said over, the issue of relations between the middle and the areas additionally happens in the truth of taking care of Covid-19 inside the unitary state structure in Indonesia. The focal government has made strides by giving a few vital arrangements to alleviate Covid-19, including Government Regulation rather than Law No. 1 of 2020 concerning State Financial Policy and Financial System Stability for Handling the 2019 Corona Virus Disease (Covid 19) Pandemic [9] nor in the Context of Facing Threats That Endanger the National Economy nor Financial System Stability, Control Regulations as the producer of standards, guidelines, techniques, and measures (NSPK) which have their obligations and capacities. In the interim, the neighborhood government as a component of the unitary state likewise holds the command of the public interest as a sub-arrangement of the National government in Government Regulation Number 21 of 2020 concerning Large-Scale Social Restrictions in the Context of Accelerating the Handling of Corona Virus Disease 2019 (Covid 2019), Presidential Decree No. 11 of 2020 concerning the Determination of the Corona Virus Disease 2019 (Covid 2019) Public Health Emergency.[10] Official Decree No. 12 of 2020 concerning the Designation of Covid 19 as a National Disaster. Clergyman of Health Regulation 9 of 2020 concerning Guidelines for Large-Scale Social Restrictions in the Context of Accelerating the Handling of Corona Virus Disease 2019 to Presidential Instruction Number 6 of 2020 with respect to Discipline Improvement and Law Enforcement of Health Protocols in the Prevention and Control of Corona Virus Disease 2019. Be that as it may, in all actuality, the enactment and the strategies gave by the focal government have not had the option to viably manage the Covid-19 pandemic in Indonesia. The obligation regarding taking care of Covid-19 is to be sure the obligation of the focal government by taking different vital approaches in Indonesia. However, many gatherings express that these arrangements are not huge enough to beat the Covid-19 pandemic for nearly 12 months. The Covid-19 taking care of strategy helped out by the focal government through $3 \mathrm{~T}$ (testing, following, treatment) and $3 \mathrm{M}$ is liable for general wellbeing and security.

Responsive and inventive activities of neighborhood state run administrations in taking strategies to beat the Covid-19 pandemic, which is some of the time actually considered inadequate in stifling the spread of Covid-19, guidelines made by the focal government are frequently late and not ready to conquer the pandemic issues required by the local area. Then again, at the territorial level, the zones government as the delegate of the focal government and individuals' agent causes different contentions with the zones government, obviously, can't be accused overall. It is on the grounds that the progressively neighborhood states are delegates of the focal government, politically nearby legislatures are agents of individuals in the locales. Furthermore, rationally, the reason for the state is to "ensure the whole Indonesian country and the whole country of Indonesia, advance public government assistance, teach the country's life, and complete world request"[11] not only the responsibility of the central government, but also the responsibility of local governments in making it happen, both in common state conditions and state emergencies such as the current Covid-19 pandemic.

\section{Conclusion}


Provincial government approaches are imperative in dealing with the Covid-19 pandemic due to the Governor's job for a considerable length of time, right off the bat with regards to a unitary state, there is a connection between the focal and local legislatures, both as far as power, finance, and administrative relations. Furthermore, there are tricky relations between the focal government and nearby state run administrations overall in taking care of Covid-19 in Indonesia brought about the ineffectualness of approaches for dealing with Covid-19 did by the focal and provincial legislatures. Third, numerous essential unofficial laws and codes have not been successful enough to beat the Covid-19 pandemic. Fourth, the territorial government as a component of the essential government and delegates of individuals in the space has direct liability to the local area for the wellbeing and security of individuals nearby. Fifth, the advancement in dealing with Covid-19 did by the local government is important for the public interest to do state objectives sticking to the solus populi suprema lex guideline.

\section{References}

[1] “Law Number 25 of 2009 concerning Public Services."

[2] Reformasi Birokrasi, Kepemimpinan, dan Pelayanan Publik: Kajian Tentang Pelaksanaan Otonomi Daerah di Indonesia [Leadership, and Public Service: A Study on the Implementation of Regional Autonomy in Indonesia]. Yogyakarta: Gramedia, 2009.

[3] A. Kurnawan, Transformasi Pelayanan Publik Pembaharuan [Public Service Transformation Renewal]. Yogyakarta: Andi Offset, 2005.

[4] P. S. Saraswati, "Kebijakan Hukum Terhadap Penanganan Pandemi Covid-19 di Indonesia [Legal Policy Against the Handling of the Covid-19 Pandemic in Indonesia]," KERTHA WICAKSANA, vol. 14, no. 2, pp. 147-152, Jul. 2020, doi: 10.22225/kw.14.2.1923.147-152.

[5] Sedarmayanti, Good Governance "Kepemerintahan Yang Baik," Bagian Ked. Bandung: Mandar Maju, 2012.

[6] H. N. Tangkilisan, Kebijakan Publik Yang Membumi [Grounded Public Policy]. Yogyakarta: Lukman Offset YPAPI, 2005.

[7] M. Makhfudz, "KONTROVERSI PELAKSANAAN OTONOMI DAERAH [CONTROLLING THE IMPLEMENTATION OF REGIONAL AUTONOMY,]," ADIL J. Huk., vol. 3, no. 2, p. 380, May 2019, doi: 10.33476/ajl.v3i2.816.

[8] A. Hamid, "Otonomi Daerah dan Pelayanan Publik [Regional Autonomy and Public Services].," J. Acad., vol. 3, no. 1, pp. 535-546, 2011.

[9] A. R. I. S. A. H. Indradi et al., "Politik Hukum Pemerintah dalam Penanganan Pandemi Covid-19 [Government Legal Politics in Handling the Covid-19 Pandemic]," Univ. Gajah Mada, 2020.

[10] H. A. Kurniawansyah, M. Salahuddin, M., and S. Nurhidayati, "Konsep Kebijakan Strategis Dalam Menangani Eksternalitas Ekonomi Dari Covid - 19 Pada Masyarakat Rentan Di Indonesia [Strategic Policy Concepts in Dealing with Economic Externalities From Covid - 19 in Vulnerable Communities in Indonesia]," Indones. J. Soc. Sci. Humanit., vol. 1, no. 2, pp. 130-139, 2020.

[11] F. A. Nasution, "KEBIJAKAN PERIMBANGAN KEUANGAN ANTARA PEMERINTAH PUSAT DAN DAERAH PASCA REFORMASI [FINANCIAL BALANCE POLICY BETWEEN CENTRAL AND REGIONAL GOVERNMENTS POSTREFORM]," J. Huk. Pembang., vol. 41, no. 4, p. 724, Dec. 2011, doi: 
10.21143/jhp.vol41.no4.257. 